\title{
RANCANG BANGUN ALAT PENDETEKSI KEBOCORAN GAS LPG DENGAN SENSOR MQ-6 BERBASIS MIKROKONTROLER MELALUI SMARTPHONE ANDROID SEBAGAI MEDIA INFORMASI
}

\author{
Mifza Ferdian Putra ${ }^{1)}$, Awang Harsa Kridalaksana ${ }^{2)}$, Zainal Arifin ${ }^{3)}$ \\ ${ }^{1,2,3)}$ Program Studi Ilmu Komputer FKTI Universitas Mulawarman \\ Jl. Barong Tongkok Kampus Gunung Kelua Kota Samarinda \\ E-Mail: mifza.ferdian99@gmail.com ${ }^{1)}$; awanghk@unmul.ac.id²); zainal.arifin@unmul.ac.id ${ }^{3)}$
}

\begin{abstract}
ABSTRAK
Peranan gas LPG pada saat ini sangatlah penting bagi kehidupan manusia baik di rumah tangga maupun di industri. Namun, gas dapat berdampak negatif, terutama bila tidak diketahui telah terjadi kebocoran dari tabung atau tempat penyimpanan gas LPG tersebut. Penyebab dari bocor tabung gas ini bisa terjadi karena kebocoran pada selang, tabung atau pada regulatornya yang tidak terpasang dengan baik dan tabung gas yang didistribusikan memang kualitasnya kurang baik atau rusak fisik. Penelitian ini bertujuan untuk menghasilkan sebuah rancang bangun alat pendeteksi kebocoran tabung gas LPG dengan menggunakan sensor MQ-6 sebagai sensor gas, dan ethernet shield sebagai modul pada mikrokontroler arduino uno untuk menghubungkan arduino dengan jaringan internet. Cara kerja alat ini yaitu, ketika sensor MQ-6 mendeteksi gas LPG maka sensor akan mengirimkan data ke mikrokontroler pada arduino untuk diberikan respon berupa menyalakan kipas, buzzer sebagai alarm, dan alat ini dapat mengirimkan informasi data analog gas ke smartphone android menggunakan plaltform Cayenne melalui jaringan internet.
\end{abstract}

Kata kunci: LPG, arduino, sensor MQ-6, cayenne

\section{Pendahuluan}

Peranan LPG (Liquefied Petroleum Gas) pada saat ini sangatlah penting bagi kehidupan manusia baik di rumah tangga maupun di industri, dan gas LPG di samping harganya murah, cara penggunaanya lebih mudah. Namun, gas LPG dapat berdampak negatif terhadap kesehatan manusia bahkan menimbulkan kerugian yang cukup besar apabila tidak digunakan dengan hati-hati, terutama bila tidak diketahui telah terjadi kebocoran dari tabung atau tempat penyimpanan gas LPG tersebut. Kebocoran tabung atau perangkat LPG sampai saat ini masih menjadi salah satu penyebab utama kebakaran. Gas LPG yang mengalami kebocoran memang tercium baunya sehingga kebocoran normal mudah dideteksi. Akan tetapi, bila gas yang bocor meresap kedalam saluran air, instalansi listrik, atau ke bawah karpet, maka akan sulit di deteksi oleh indra penciuman manusia. Selain itu AC dan pemanas ruangan juga dapat menutupi bau gas LPG. Gas LPG terkenal dengan sifatnya yang mudah terbakar sehingga kebocoran peralatan LPG beresiko tinggi terhadap kebakaran. Dikarenakan sifatnya yang sensitif, maka perlu adanya perhatian khusus terhadap bahan bakar jenis ini. Sehingga diperlukan suatu sistem peringatan dini dalam menannggulangi kebocoran gas.

Mengacu pada penelitian sebelumnya yang berjudul "Rancang Bangun Alat Deteksi Kebocoran Gas LPG Berbasis Arduino" yang dilakukan oleh
Widyanto tahun 2014 juga membahas tentang pendeteksi kebocoran gas LPG menggunakan mikrokontroler arduino, dimana penelitian tersebut menghasilkan sistem detektor gas.

Berdasarkan uraian tersebut, penulis tertarik untuk membuat suatu alat pendeteksi kebocoran gas dengan menggunakan mikrokontroler yang dapat memonitoring adanya kebocoran gas yang dapat diamati secara langsung melalui smartphone android dalam bentuk grafik. Mikrokontroler yang digunakan berbasis ATMEGA328, sensor MQ-6 sebagai modul sensor khusus untuk gas LPG dan modul ethernet shield arduino sebagai media transfer data dari mikrokontroler ke smartphone android melalui jaringan internet. Sistem ini dilengkapi dengan buzzer sebagai sirine dan informasi data analog yang nantinya akan tampil pada smartphone android.

\section{TINJAUAN PUSTAKA}

\subsection{Mikrokontroler}

Mikrokontroler merupakan suatu IC yang di dalamnya berisi CPU, ROM, RAM, dan I/O. Dengan adanya CPU tersebut maka mikrokontroler dapat melakukan proses berfikir berdasarkan program yang telah diberikan kepadanya. Mikrokontroler banyak terdapat pada peralatan elektronik yang serba otomatis, mesin fax, dan peralatan elektronik lainnya. Mikrokontroler dapat disebut pula sebagai komputer yang berukuran kecil yang berdaya 
rendah sehingga sebuah baterai dapat memberikan daya.

Mikrokontroler standar memiliki komponenkomponen sebagai berikut [2]:

a. Central Processing Unit (CPU) merupakan bagian utama dalam suatu mikrokontroler. CPU pada mikrokontroler ada yang berukuran 8 bit ada pula yang berukuran 16 bit. CPU ini akan membaca program yang tersimpan di dalam ROM dan melaksanakannya.

b. Read Only Memory (ROM) merupakan suatu memori (alat untuk mengingat) yang sifatnya hanya dibaca saja. Dengan demikian ROM tidak dapat ditulisi. Dalam dunia mikrokontroler ROM digunakan untuk menyimpan program bagi mikrokontroler tersebut. Program tersimpan dalm format biner ('0' atau ' 1 '). Susunan bilangan biner tersebut bila telah terbaca oleh mikrokontroler akan memiliki arti tersendiri.

c. Random Acces Memory (RAM) berbeda dengan ROM, RAM adalah jenis memori selain dapat dibaca juga dapat ditulis berulang kali. Tentunya dalam pemakaian mikrokontroler ada semacam data yang bisa berubah pada saat mikrokontroler tersebut bekerja. Perubahan data tersebut tentunya juga akan tersimpan ke dalam memori. Isi pada RAM akan hilang jika catu daya listrik hilang.

d. Input/Output (I/O) untuk berkomunikasi dengan dunia luar, maka mikrokontroler menggunakan terminal I/O (port I/O), yang digunakan untuk masukan atau keluaran.

e. Komponen lainnya Beberapa mikrokontroler memiliki timer atau counter, ADC (Analog to Digital Converter), dan komponen lainnya. Pemilihan komponen tambahan yang sesuai dengan tugas mikrokontroler akan sangat membantu perancangan sehingga dapat mempertahankan ukuran yang kecil. Apabila komponen komponen tersebut belum ada pada suatu mikrokontroler, umumnya komponen tersebut masih dapat ditambahkan pada sistem mikrokontroler melalui port-portnya.

\subsection{Arduino}

Arduino didefinisikan sebagai sebuah platform elektronik yang open source, berbasis pada software dan hardware yang fleksibel dan mudah digunakan, yang ditujukan untuk seniman, desainer, hobbies dan setiap orang yang tertarik dalam membuat objek atau lingkungan yang interaktif. Arduino sebagai sebuah platform komputasi fisik (Physical Computing) yang open source pada board input ouput sederhana, yang dimaksud dengan platform komputasi fisik disini adalah sebuah sistem fisik hyang interaktif dengan penggunaan software dan hardware yang dapat mendeteksi dan merespons situasi dan kondisi.
Kelebihan arduino dari platform hardware mikrokontroler lain adalah [4]:

a. IDE Arduino merupakan multiplatform, yang dapat dijalankan di berbagai sistem operasi, seperti Windows, Macintosh dan Linux.

b. IDE Arduino dibuat berdasarkan pada IDE Processing, yang sederhana sehingga mudah digunakan.

c. Pemrograman arduino menggunakan kabel yang terhubung dengan port USB, bukan port serial. Fitur ini berguna karena banyak komputer yang sekarang ini tidak memiliki port serial.

d. Arduino adalah hardware dan software open source pembaca bisa men-download software dan gambar rangkaian arduino tanpa harus membayar ke pembuat arduino.

e. Biaya hardware cukup murah, sehingga tidak terlalu menakutkan untuk membuat kesalahan.

f. Proyek arduino ini dikembangkan dalam lingkungan pendidikan sehingga bagi pemula akan lebih cepat dan mudah mempelajarinya.

g. Memiliki begitu banyak pengguna dan komunitas di internet dapat membantu setiap kesulitan yang dihadapi.

\subsection{Sensor Gas MQ-6}

Sensor MQ 6 adalah sensor gas yang cocok untuk mendeteksi gas LPG (Liquefied Petroleum Gas), dapat mendeteksi gas LPG dan termasuk gas yang terdiri dari dalam gas LPG yaitu gas propana dan butana. Sensor ini dapat mendeteksi gas pada konsentrasi di udara antara 200 sampai 10000 ppm. Sensor ini memiliki sensitivitas yang tinggi dan waktu respon yang cepat. Output sensor adalah resistansi analog. Sirkuit dari sensor ini sangat sederhana, yang diperlukan sensor ini adalah memberi tegangan dengan $5 \mathrm{~V}$, menambahkan resistansi beban, dan menghubungkan output ke ADC.

\subsection{Cayenne}

Cayenne adalah sebuah platform cloud yang menyediakan sebuah layanan backend bagi para pencipta IoT. Para pengembang IoT dapat dengan mudah mendesain serta membangun sebuah proyek yang berhubungan dengan IoT. Dengan menggunakan platform cloud ini dapat menhubungkan hardware dengan software yang telah dirancang pada board mikrokontroler. Berikut beberapa komponen yang terdapat pada platform ini:

a. Aplikasi Mobile Cayenne: digunakan untuk mengontrol dan memonitor proyek IoT langsung dari Android.

b. Dashboard Cayenne: digunakan untuk mengubah dan mendesain fitur dalam memvisualisasikan data. 
Cayenne merupakan salah satu bagian terpenting untuk menampilkan informasi dari sistem pendeteksi kebocoran gas. Sebelum menggunakan aplikasi cayenne pengguna harus mendaftarkan akun terlebih dahulu di www.cayenne-mydevices.com. Setelah memilki akun, selanjutnya mengkonfigurasikan antara arduino board yang sudah terpasang dengan ethernet shield ke cayenne. Pastikan bahwa board arduino telah terhubung ke internet. Setelah berhasil melakukan komunikasi antara arduino dengan cayenne, maka langsung bisa melakukan kustomisasi penambahan widget berupa grafik dan bisa melakukan trigger short message service dan email kepada pengguna.

\section{HASIL DAN PEMBAHASAN}

\subsection{Deskripsi Sistem}

Sistem pendeteksi kebocoran gas LPG menggunakan mikrokontroler Arduino Uno R3, Sensor MQ-6, Ethernet Shield Arduino, dan modem yang manfaatnya adalah memberi informasi serta peringatan dini apabila terjadi kebocoran gas pada suatu ruangan. Dalam sistem ini menggunakan sensor sebagai indikator atau inputan dalam membaca kadar gas.

Penggunaan alat ini akan berjalan otomatis berdasarkan perintah-perintah atau source code yang ditanam dalam mikrokontroler tersebut. Pada kondisi dalam keadaan gas bocor maka sensor akan mengirim perintah untuk menyalakan output buzzer yang memberikan peringatan bahwa telah terjadi kebocoran gas dan kipas akan menyala bekerja untuk mengeluarkan gas yang bocor pada suatu ruangan. Alat pada sistem ini juga mengirimkan informasi atau memonitoring kadar gas yang bocor ke smartphone andoid yang dapat diakses mealalui aplikasi platform cayenne.

\subsection{Perancangan Alat}

Pembuatan sistem pendeteksi kebocoran gas LPG ini melalui beberapa tahap pembuatan. Dimulai dengan mempersiapkan bahan dan alat yang digunakan. Seperti menyiapkan box dan penyusunan mainboard arduino dengan Ethernet Shield Arduino. Maksud dari pembuatan box yaitu untuk peletakkan komponen-komponen input dan output atau sebagai wadah dari sistem alat ini agar dapat memudahkan dan menyesuaikan sistem dalam penggunaannya. Proses selanjutnya yaitu proses perangkaian skematik elektronik sistem pendeteksi kebocoran gas.

\subsection{Pembuatan Rangkaian}

Pada tahap pembuatan rangkaian ini yang dilakukan adalah mempersiapkan komponen yang yang akan digunakan seperti, Sensor MQ-6,
Arduino Uno R3 dengan Ethernet Shield dan beberapa kabel. Pada Arduino Uno sudah disematkan mikrokontroler ATMEGA 328, yang memiliki 14 pin input/output digital (6 output untuk PWM), dan 6 pin analog input. Rangkaian elektronik arduino memiliki beberapa komponen lainnya seperti IC regulator yang berfungsi sebagai kebutuhan rangkaian power supply.

Sebagai sumber tegangan dalam rangkaian ini mengunakan adaptor 12 volt. Untuk rangkaian sensor MQ-6 mendapatkan input-an listrik sebesar $5 \mathrm{~V}$ dan menggunakan pin A0 untuk memberi inputan ke mikrokontroler/arduino, pada buzzer menggunakan pin D7 untuk memberi output, sedangkan untuk led dan kipas terhubung dengan rangkaian relay. Pada gambar 1 merupakan perancangan komponen rangkaian secara keseluruhan yang masih menggunakan breadboard.

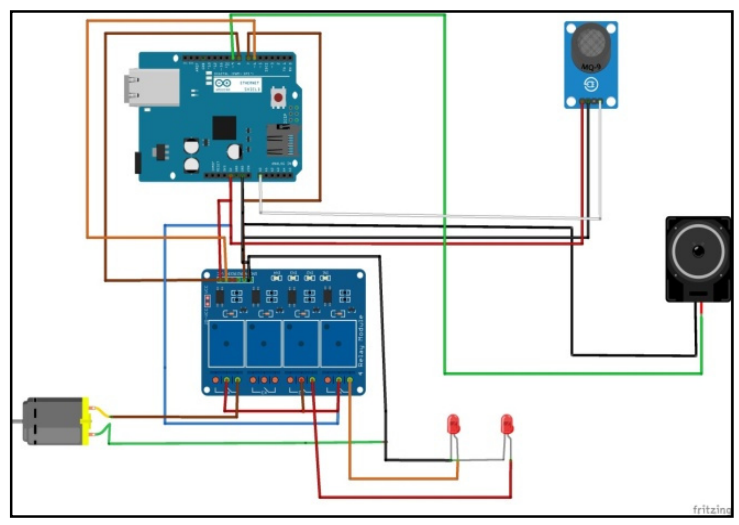

Gambar 1. Rangkaian Pemasangan Komponen

\subsection{Perancangan Program}

Perancangan program sistem pendeteksi kebocoran gas ini terdiri dari beberapa tahapan. Proses pertama adalah pembuatan flowchart dari sistem pendeteksi kebocoran gas, kemudian program dibuat menggunakan Arduino IDE menggunakan bahasa $\mathrm{C}$ dan program inilah yang akan menjalankan perintah-perintah pada sistem dan alat. Kemudian program yang telah di upload ke mikrokontroler menggunakan Arduino IDE akan dihubungkan ke aplikasi platform cayenne untuk menampilkan informasi monitoring dari kebocoran gas pada android. Sebelumnya pada aplikasi cayenne harus mendaftar terlebih dahulu menggunakan email untuk dapat menggunakan fitur yang ada di dalamnya.

Pada saat program pertama kali dijalankan, sistem akan melakukan proses insialisasi input dan output yang digunakan untuk dihubungkan dengan device luar seperti sensor, buzzer, led, dan kipas. Selanjutnya mikrokontroler akan melakukan proses pembacaan kondisi dari sensor gas. Jika mendeteksi adanya gas maka lampu led merah akan menyala, bunyi alarm akan ikut aktif, dan kipas secara otamatis akan menyala. Jika sensor tidak mendeteksi adanya gas maka sistem akan kembali 
melakukan pembacaan kondisi sensor secara terus menerus sampai mendeteksi kembali adanya gas yang bocor.

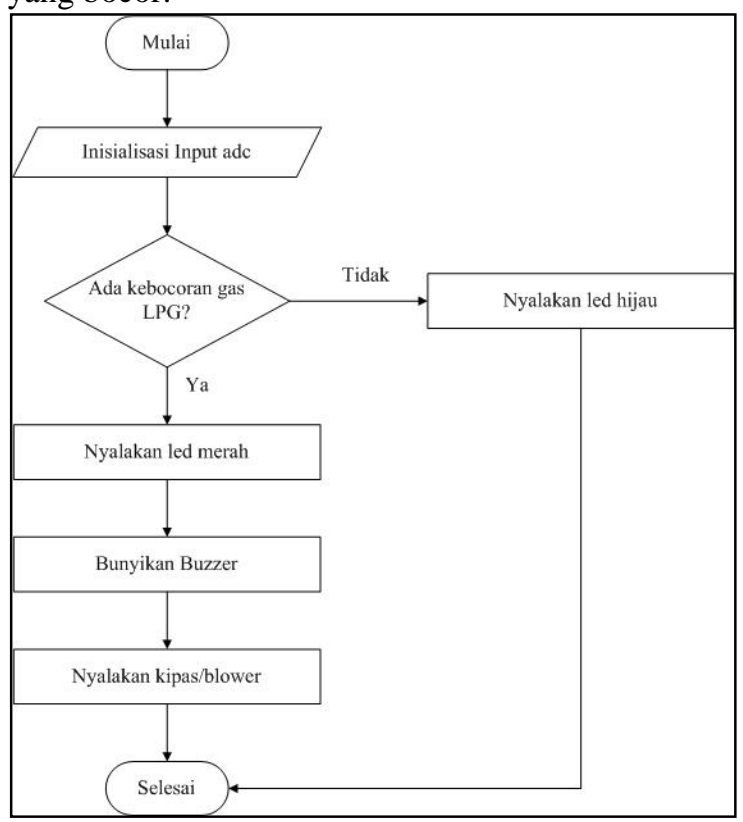

Gambar 2. Flowchart Sistem

Program pada sistem pendeteksi sistem kebocoran gas LPG ini dibuat dengan menggunakan aplikasi Arduino IDE dan memanfaatkan aplikasi platform cayenne yang menampilkan informasi grafik dan data analog. Program akan menerima input-an dari sensor MQ6 , juga memberikan data analog yang dikirim melalui jaringan internet dan dapat diakses dengan mengunakan aplikasi cayenne. Penulisan program menggunakan bahasa $\mathrm{C}$ yang telah di coding menggunakan program Arduino IDE.

Namun disini sudah banyak sintaks-sintak yang dipermudah sehingga sangat mudah dalam memprogramnya, seperti pada gambar 3. Secara umum program dalam Arduino tersebut dibagi menjadi 2 bagian besar yaitu bagian yang sekali dijalankan dan bagian yang terus-menerus di jalankan (loop). Bagian pertama akan didahului dengan kata tercadang void setup() sedangkam bagian yang dijalankan berulang-ulang didahului dengan kata tercadang void loop().

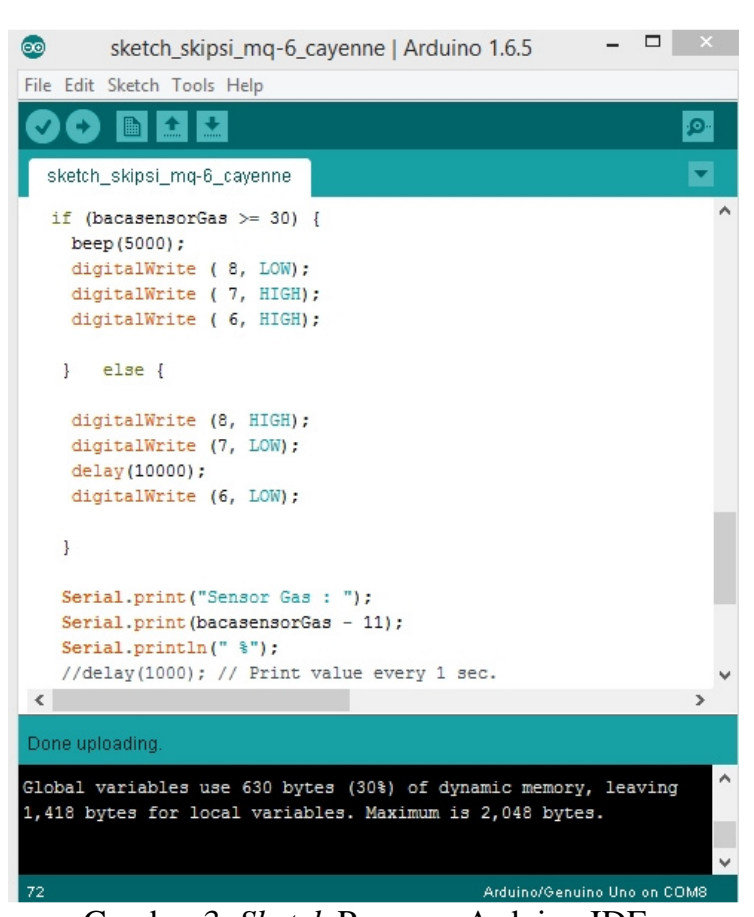

Gambar 3. Sketch Program Arduino IDE

\subsection{Implementasi}

Setelah sistem dibangun berdasarkan rancangan-rancangan yang telah dibuat maka langkah berikutnya adalah melakukan upload program. Hubungkan kabel USB dengan board arduino Uno dan pada sisi lainnya dihubungkan dengan komputer. Buka program Arduino IDE kemudian open sketch program sistem pendeteksi kebocoran gas yang telah dibuat, selanjutnya tekan tombol upload pada Arduino IDE agar sketch ditransfer dari komputer ke board arduino. Setelah selesai melakukan upload, maka kabel USB dapat dilepas dan alat sistem pendeteksi kebocoran gas dapat bekerja tanpa bantuan komputer lagi.

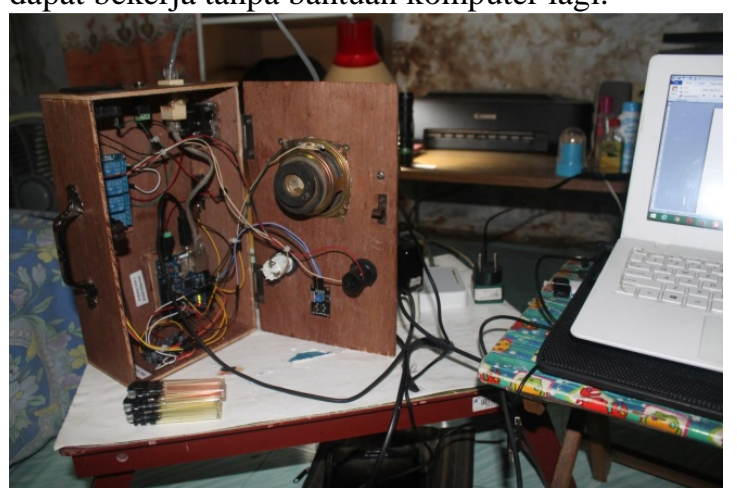

Gambar 4. Proses Upload Program Arduino IDE

Rangkaian pada gambar 4 menunjukkan proses upload sketch program sistem pendektesi kebocoran gas dari arduino IDE ke mikrokontroler. 


\subsection{Pengujian Sistem}

Dalam tahap yang terakhir ini semua komponen telah telah terhubung dengan baik dan memiliki program di dalam mikrokontroler. Pengujian ini dilakukan menggunakan peraga simulasi dengan menggunakan korek gas untuk mengaktifkan sensor MQ-6 dalam mendeteksi gas. Cara kerja perangkat ini yaitu dengan menghubungkan ke sumber daya menggunakan adaptor 12 volt dan tekan tombol ON/OFF yang terletak di samping kanan box. Pada perangkat sistem untuk menyalakan sistem ditandai dengan lampu led hijau menyala. Perangkat juga telah dihubungkan dengan router di-setting sebagai access point supaya bisa terkoneksi dengan jaringan internet. Terlihat pada gambar 5 menunjukkan bahwa perangkat sistem telah aktif. Lampu led merah pada relay menyala dan lampu led kuning pada arduino juga menyala menandakan koneksi arduino dengan router telah terhubung.

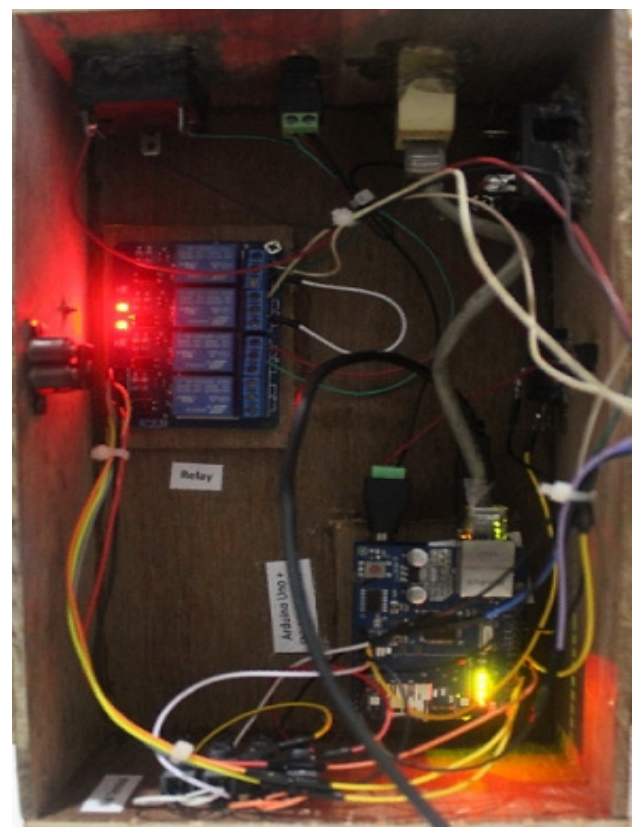

Gambar 5. Pengujian Sistem

Jika langkah awal untuk pengujian sistem sudah dilakukan maka operasi bisa dilakukan, yang perintahnya merupakan pendeteksian sensor gas Propana. Sebagaimana komponen utama mikrokontroler bekerja dengan menjalankan perintah yang telah di input-kan sebelumnya berupa coding, dimana coding tersebut mewakili perintah untuk menjalankan sensor MQ-6, lampu led, buzzer, dan kipas. Sehingga menghasilkan beberapa output berupa sensor gas mendeteksi gas propana, buzzer akan menyala, kipas berputar, dan perangkat akan mengirimkan informasi berupa data grafik ke cayenne yang dapat dibuka dengan android ataupun web. Pengujian simulasi perangkat ini bertujuan untuk melihat apakah sensor, mikrokontroler dan program telah berjalan dengan baik.

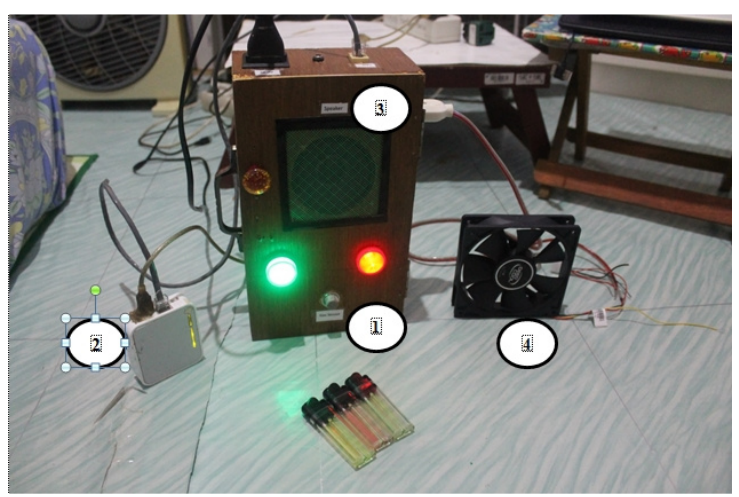

Gambar 6. Detail Hasil Rangkaian Alat

Pada gambar 6 terlihat bagian utama yang terpasang pada perangkat ini yaitu:

1. Sensor gas MQ-6 sebagai sensor gas.

2. Modem Router untuk menghubungkan perangkat ke jaringan internet.

3. Speaker sebagai alarm peringatan jika terjadi kebocoran.

4. Kipas sebagai penetralisir bau gas.

Saat mikrokontroler bekerja dan sensor aktif, pada komputer akan menampilkan serial monitor sensor gas dari aplikasi arduino IDE untuk memantau kondisi kebocoran gas seperti pada gambar 7. Kondisi nilai presentase tingkat kebocoran gas yang diberikan yaitu jika nilai lebih dari sama dengan 30\%, maka sensor MQ-6 akan membaca bahwa telah terjadi kebocoran dan akan memberi peringatan dengan adanya bunyi alarm. Jika tidak mendeteksi kebocoran maka nilai presentase sama dengan $0 \%$. Adapun algoritma dari pendeteksian gas adalah dengan menggunakan satuan presentase. Cara ini digunakan untuk memudahkan dalam pembuatan koding program.

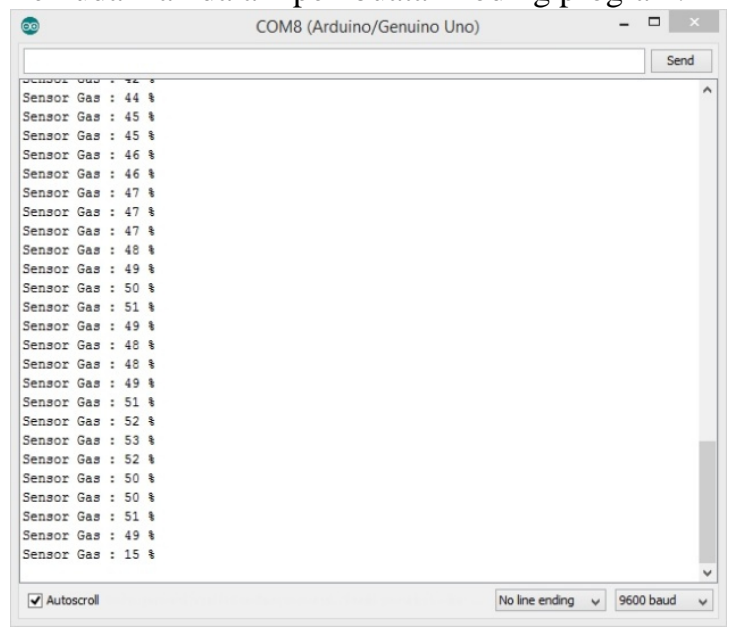

Gambar 7. Tampilan Serial Monitor Sensor Gas Mendeteksi Kebocoran

Secara otomatis juga sistem akan mengirim trigger email dan sms kepada pengguna, yang sudah di setting pada cayenne menu trigger. Pada gambar 8 adalah email yang dikirimkan bahwa sensor membaca nilai inputan lebih dari 400. 


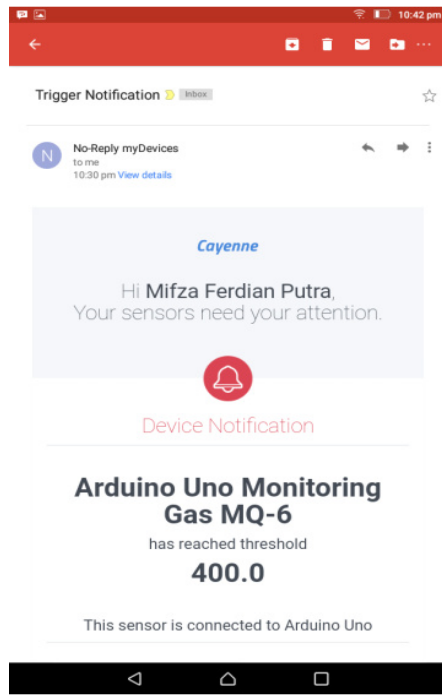

Gambar 8. Tampilan Peringatan Email

Pada saat belum terjadinya kebocoran gas, perangkat akan mengirim data analog dalam bentuk grafik yang dibuka melalui aplikasi cayenne. Grafik secara live akan menampilkan data awal yang bernilai 110 yang dibaca oleh sensor gas seperti terlihat pada gambar 9 .

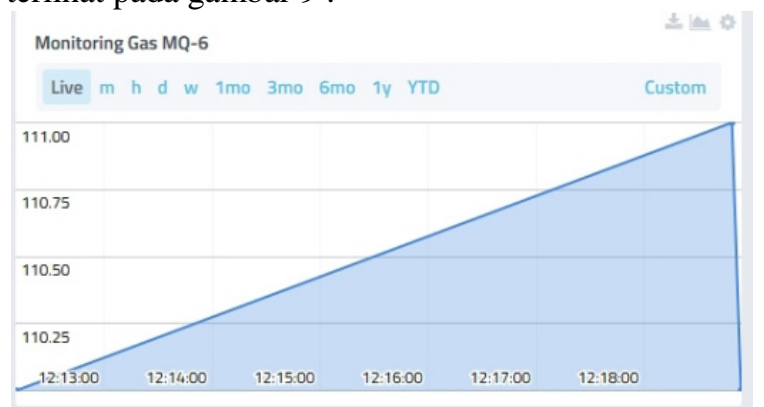

Gambar 9. Grafik Monitoring Gas Dengan Cayenne Data Awal

Dan pada saat terjadi kebocoran gas maka, grafik akan naik dari tadi awal yang bernilai 110120 menjadi 600, kemudian akan kembali normal lagi membaca data awal secara live yaitu antara 110-120. Pada gambar 10 menunjukkan bahwa telah terjadi kebocoran gas.

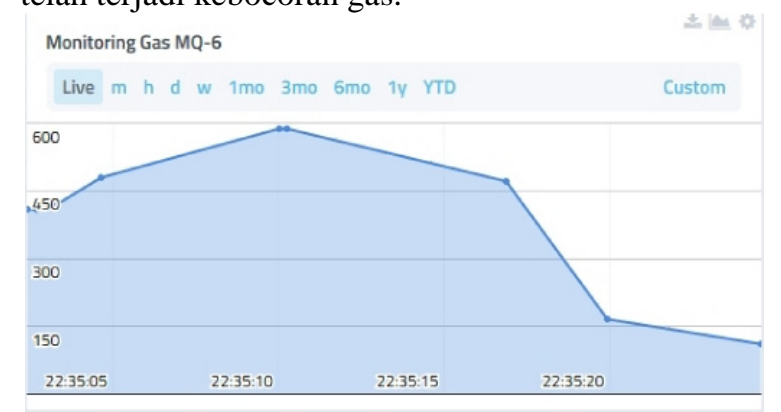

Gambar 10. Grafik Monitoring Gas Dengan Cayenne Telah Tejadi Kebocoran

Dilihat pada tabel 1 hasil pengujian sensor gas MQ-6, yaitu kondisi dan data ADC.
Tabel 1. Hasil Pengujian Sensor MQ-6

\begin{tabular}{|c|c|c|}
\hline NO. & Kondisi & Data ADC \\
\hline $\mathbf{1}$ & Tidak Ada Gas LPG & $110-120$ \\
\hline $\mathbf{2}$ & Ada Gas LPG & 800 \\
\hline
\end{tabular}

Data ADC yang terdapat pada tabel 4.1 sesuai dengan rumus :

$$
\mathrm{ADC}=(\text { Vin / Vref }) \times 1023
$$

Dimana Vin adalah tegangan keluaran dari sensor, Vref adalah tegangan referensi (5Volt) dan 1023 adalah jumlah total bit pada ADC mikrokontroler atmega328 pada arduino yaitu 10 bit. Pada penelitian ini level indikator yang digunkaan hanya 2 saja (ada gas LPG dan tidak ada gas LPG). Rentang pembacaan ADC dari sensor MQ-6 yaitu dari 110 sampai 800 .

\section{KESIMPULAN}

Berdasarkan dari keseluruhan sistem mulai dari perancangan serta pembuatan alat yang telah dilakukan, penulis memiliki beberapa kesimpulan antara lain:

1. Alat pendeteksi kebocoran gas LPG dapat bekerja dengan baik. Hal ini ditunjukkan dengan berfungsinya alat saat diberikan gas LPG. Buzzer berbunyi, kipas menyala dan menampilkan data grafik pada android.

2. Sensor akan mendeteksi adanya kebocoran pada tabung gas, apabila di dekat sekitar regulator tabung gas benar-benar terdapat kandungan gas propana.

3. Alat ini dapat mengetahui dan memudahkan pengguna mengetahui terjadinya kebocoran pada tabung gas LPG.

\section{DAFTAR PUSTAKA}

[1] Berlilana, Agung Prasetyo, Ika Marlisa Raharjo. 2016. Alat Pendeteksi Dan Pengaman Kebocoran Gas LPG Melalui SMS Berbasis Mikrokontroler ATMEGA328. Purwokerto: STMIK AMIKOM Purwokerto.

[2] Malik, Moh. Ibnu. 2003. Belajar Mikrokontroler PIC 16F 84. Yogyakarta: Gava Media.

[3] Muhammad Isra Triyandana, Abdul Muid, Tedy Rismawa. 2015. Pendeteksi Gas LPG Dan Metana Dengan Sensor TGS 2610 Dan Sensor TGS 2611 Berbasis Mikrokontroler ATMEGA328P. Pontianak: Universitas Tanjungpura Pontianak

[4] Putra, Lucky Yuditia. 2013. Modul Latih Mikrokontroler Arduino Uno untuk Mengontrol Suhu Ruangan dengan Menggunakan Sensor Suhu, Kipas dan Liquid Crystal Display. Jakarta: Universitas Mercu Buana Jakarta.

[5] Widyanto, Deni Erlansyah. 2014. Rancang Bangun Alat Deteksi Kebocoran Tabung Gas Elpiji Berbasis Arduino. Palembang: Universitas Bina Darma Palembang. 